\begin{tabular}{|c|l|}
\hline Title & $\begin{array}{l}\text { Low genetic diversity in an isolated red fox (V ul pes vul pes) population on Mt. Hakodate, Japan, revealed by } \\
\text { microsatellite analy ses of fecal samples }\end{array}$ \\
\hline Author(s) & A maike, Y osuke; Murakami, Takahiro; Masuda, Ryuichi \\
\hline Citation & $\begin{array}{l}\text { Mammal study, 43(3), 141-152 } \\
\text { https://doi.org/10.3106/ms2017-0055 }\end{array}$ \\
\hline Issue Date & 2018-09 \\
\hline Doc URL & http://hdl.handle.net/2115/75321 \\
\hline Type & article \\
\hline File Information & ms2017-0055.pdf \\
\hline
\end{tabular}

Instructions for use 


\section{BioOne COMPLETE}

\section{Low genetic diversity in an isolated red fox (Vulpes vulpes) population on Mt. Hakodate, Japan, revealed by microsatellite analyses of fecal samples}

Authors: Yosuke Amaike, Takahiro Murakami, and Ryuichi Masuda

Source: Mammal Study, 43(3) : 141-152

Published By: Mammal Society of Japan

URL: https://doi.org/10.3106/ms2017-0055

BioOne Complete (complete.BioOne.org) is a full-text database of 200 subscribed and open-access titles in the biological, ecological, and environmental sciences published by nonprofit societies, associations, museums, institutions, and presses.

Your use of this PDF, the BioOne Complete website, and all posted and associated content indicates your acceptance of BioOne's Terms of Use, available at www.bioone.org/terms-of-use.

Usage of BioOne Complete content is strictly limited to personal, educational, and non-commercial use. Commercial inquiries or rights and permissions requests should be directed to the individual publisher as copyright holder.

BioOne sees sustainable scholarly publishing as an inherently collaborative enterprise connecting authors, nonprofit publishers, academic institutions, research libraries, and research funders in the common goal of maximizing access to critical research. 


\title{
Low genetic diversity in an isolated red fox (Vulpes vulpes) population on Mt. Hakodate, Japan, revealed by microsatellite analyses of fecal samples
}

\author{
Yosuke Amaike ${ }^{1}$, Takahiro Murakami ${ }^{2}$ and Ryuichi Masuda ${ }^{1, *}$ \\ ${ }^{1}$ Department of Biological Sciences, Faculty of Science, Hokkaido University, Sapporo 060-0810, Japan \\ ${ }^{2}$ Institute of Decision Science for Sustainable Society, Kyushu University, Fukuoka 819-0395, Japan
}

\begin{abstract}
Mt. Hakodate, Hokkaido, is a small mountain geographically isolated by the sea and urban area, and some red foxes (Vulpes vulpes) live there. In consideration of the specific geographical environment, we made a hypothesis that the fox population on Mt. Hakodate is small in size and isolated, and consequently its genetic variation is low, and then tested it. To investigate the genetic variation, we genotyped microsatellite loci using fecal samples collected noninvasively from 2009 to 2011. As the result, we successfully identified 35 foxes for the three years (12 in 2009, 11 in 2010, and 22 in 2011), and presumed eight of them were adults, indicating that the population size is extremely small. The genetic structures and degree of differentiations showed that the Mt. Hakodate population was genetically differentiated from those of the other populations. The urban area of Hakodate City could have played a role of a dispersal barrier for foxes. Additionally, the genetic diversity of the Mt. Hakodate population was lower than those of the other populations in Hokkaido. Our results suggested that the Mt. Hakodate population have low genetic diversity due to restricted gene flow and the small population size, supporting our hypothesis.
\end{abstract}

Key words: genetic structure, individual identification, noninvasive sample, population size.

The red fox, Vulpes vulpes (Carnivora: Canidae), is widely distributed across the northern hemisphere from the Arctic Circle to North Africa, Central America, the Asiatic steppes, and Australia (an introduced population), and has adapted to diverse environments including tundra, desert, forest, and urban areas (Macdonald and Reynolds 2008). The red fox also occurs on some small islands such as Assateague Island in the United States (Paradiso and Handley 1965) and Prince Edward Island in Canada (Sobey 2007). In Japan, one subspecies, $V . v$. schrencki, inhabits Hokkaido Island (Uraguchi 2015), and one of its populations is distributed on Mt. Hakodate, which is geographically isolated as "a land-tied island" (Kimura 2011).

Mt. Hakodate $\left(41^{\circ} 45^{\prime} 32^{\prime \prime} \mathrm{N}, 140^{\circ} 42^{\prime} 15^{\prime \prime} \mathrm{E}\right)$, located near the base of the Kameda Peninsula, southern Hokkaido (Fig. 1A, 1B), is $334 \mathrm{~m}$ in altitude, roughly $9 \mathrm{~km}$ in circumference, and 326 ha in area. It is surrounded on three sides by the sea and on the landward side abuts the city of Hakodate (Fig. 1C). Mt. Hakodate was protected as a military area from 1898 to 1945 , and its natural environment remained relatively undisturbed for nearly half a century (Munakata 1980). The Hokkaido Government has designated Mt. Hakodate as a Wildlife Protection Area (353 ha) and Wildlife Special Protection Area (327 ha) (Hakodate City 2016). Though it borders a crowded urban area, it supports more than 600 plant species (Sugawara and Komatsu 1959) and provides habitat for both resident and migrating birds, of which approximately 150 species can be seen year-around (Munakata 1980). In mammal species other than the red fox, the chipmunk (Tamias sibiricus), introduced Japanese weasel (Mustela itatsi), two species of any mice (or shrews), and two bat species are distributed there (Kimura 2011). Vegetation and bird surveys have been conducted on Mt. Hakodate in the past because of the high diversity of species, but until now there have been no scientific studies on the resident terrestrial mammals including red foxes.

DNA analyses using noninvasively collected fecal samples can provide many kinds of biological informa-

*To whom correspondence should be addressed.E-mail: masudary@sci.hokudai.ac.jp 
tion of target animals. For example, species and individual identifications have been often performed to obtain ecological data without harming animals. Kurose et al. (2005) analyzed the DNA from fecal samples to identify species and sex for four carnivore species, including the endangered Tsushima leopard cat (Prionailurus bengalensis), on Tsushima Island, Nagasaki Shimatani et al. $(2008,2010)$ likewise genetically identified five carnivore species from fecal samples collected in the Kushiro wetland, Hokkaido, and successfully identified individuals of the American mink (Neovison vison) there. Oishi et al. (2010) analyzed 59 fecal samples from red foxes in the Shiretoko National Park, Hokkaido, and ascertained that they derived from 22 individuals. This analysis can also provide much information important to conservation, such as population size, population structure, gene flow, and sex (Frankham 2010). Saito et al. (2016) identified 31 individuals from raccoon dog (Nyctereutes procyonoides) fecal samples on the grounds of the Imperial Palace, Tokyo, and examined the genetic structure of that population. Dallas et al. (2003) determined the sex from feces of the Eurasian otter (Lutra lutra), and attempted to estimate the sex ratio. Sex identification for red foxes has been previously conducted by using sex-specific markers designed based on genes on the Y chromosome, such as the $Z F Y$ gene (Ortega et al. 2004), SRY gene (Berry et al. 2007), and amelogenin gene (Moore et al. 2010).

Generally, isolated and small populations have low genetic variation due to genetic drift, restricted gene flow, and inbreeding. In fact, the phenomena have seen in various animals such as the Galápagos penguin (Spheniscus mendiculus) (Nims et al. 2008), platypus (Ornithorhynchus anatinus) (Furlan et al. 2012), and Blakiston's fish owl (Bubo blakistoni) (Kohyama et al. 2015). In the present study, we made three hypotheses that the fox population on Mt. Hakodate is (1) small in size and (2) isolated, and consequently (3) its genetic variation is low. We then attempted to test the hypotheses. First, we determined microsatellite genotypes from fecal sample collected on Mt. Hakodate in order to identify individuals and to estimate population sizes. Then, we characterized the genetic structure of the population to determine whether the gene flow is restricted. Finally, we calculated indices of diversity to assess the genetic variation in the population. Furthermore, we designed a new sex-specific marker optimized for fecal DNA of foxes, and applied it to the field samples in this study to confirm the efficacy.

\section{Materials and methods}

\section{Sampling and DNA extraction}

Fecal samples were collected along nine hiking-trail courses on Mt. Hakodate (Irie-yama, Kannon, Yakushiyama, Kyu-tozando, Shiomi-yama, Senjojiki, Nanamagari, Miyanomori, and Ezodate-yama), and from three towns (Kaminokuni, Matsumae, and Shikabe) in the southern part of the Oshima Peninsula (SOP) (Fig. 1). The continual fieldwork on Mt. Hakodate, designed so that all the hiking courses could be checked within the span of a month, was conducted one or more times per month in April-December 2009, April-November 2010, and April-December 2011. The sampling effort is not different substantially from year to year. One-off fieldwork was conducted also in Kaminokuni, Matsumae, and Shikabe in October or November 2011. Feces found in the field were placed into gamma-sterilized polypropylene conical tubes with sterilized forceps. Locations were determined with a handheld global positioning system (GPS) unit (GPS-CS3K, Sony) or a digital camera with a built-in GPS (Optio WG-1 GPS, Pentax). Fecal samples were transported to the laboratory at room temperature and then stored at $-80^{\circ} \mathrm{C}$ for a week or more prior to DNA extraction, in order to inactivate tapeworm (Echinococcus multilocularis) eggs.

Total DNA was extracted from approximately $0.3 \mathrm{~g}$ of each fecal sample by using the QIAamp DNA Stool Mini Kit (Qiagen). As a positive control, DNA was extracted from the muscle tissue of a road-killed cub by using the DNeasy Blood \& Tissue Kit (Qiagen).

\section{Species-specific mitochondrial DNA amplification}

To verify that the collected feces were from the red fox, a part of the mitochondrial DNA (mtDNA) control region was amplified by polymerase chain reaction (PCR) with a red fox-specific primer pair fox-F1/R1 (Shimatani et al. 2008). To identify other mammal species presumed to occur on Mt. Hakodate, PCRs were performed with primer pairs specific for the domestic dog (Canis familiaris) (Shimatani et al. 2008) and domestic cat (Felis catus) (Kurose et al. 2005). The species-specific PCR amplifications were performed for all fecal DNA samples at least twice by following the protocols used in the previous studies.

\section{Microsatellite genotyping}

Genotyping was attempted for each fecal DNA sample identified as originating from the red fox. Initially the 

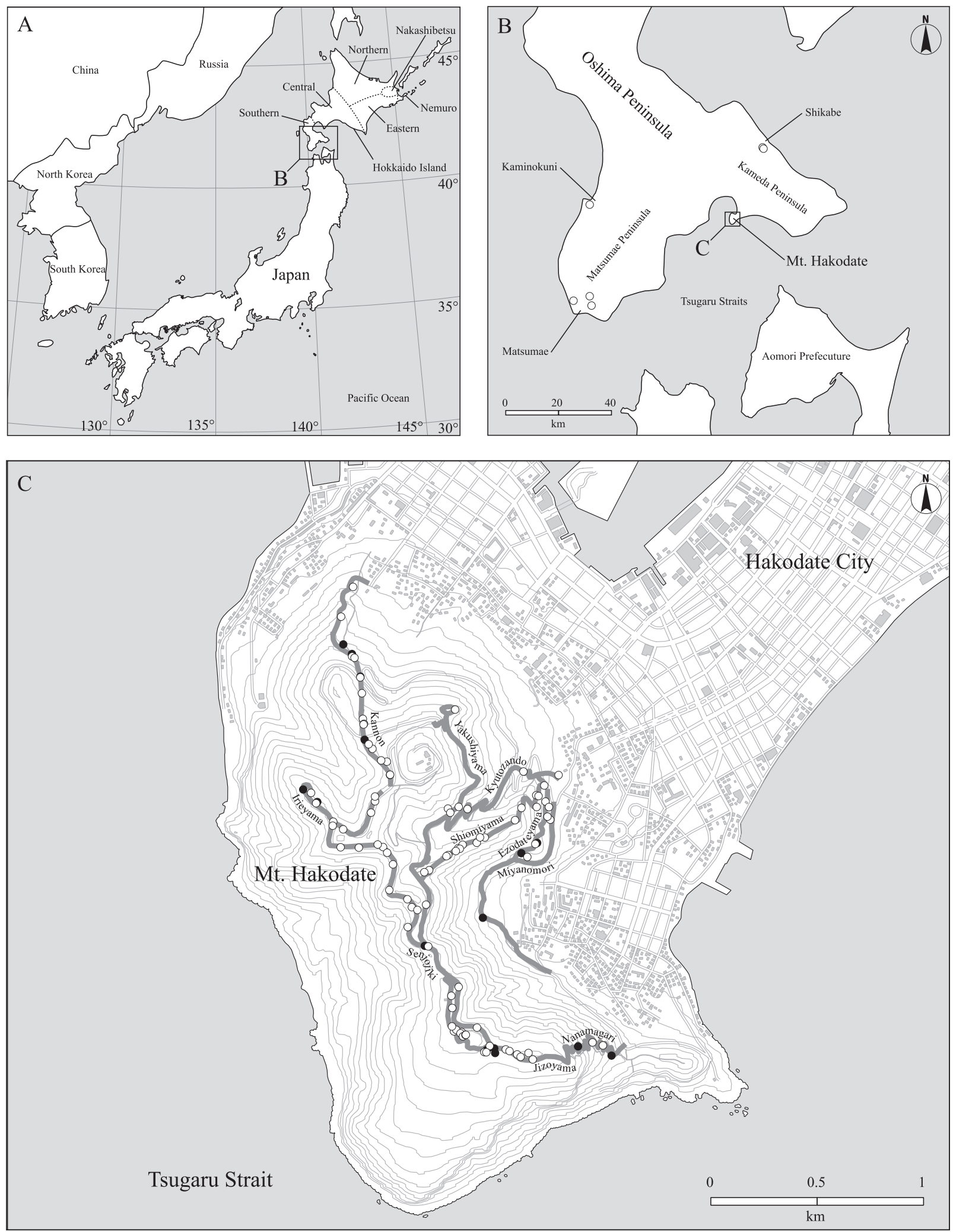

Fig. 1. Sampling locations and points where fecal samples were obtained. (A) A map of East Asia and Japan. Dashed lines on Hokkaido Island indicate boundaries of red fox populations based on Oishi et al. (2011). (B) A map of the south part of the Oshima Peninsula (SOP) (enlargement of the boxed area in A). (C) A map of Mt. Hakodate (enlargement of the boxed area in B). The map in C was drawn Quantum GIS 1.7.1 Wroclaw (QGIS Development Team 2011) using GIS Base Map Information obtained from the Geospatial Information Authority of Japan (http://www.gsi.go.jp/ kiban/). Open and closed circles indicate red foxes and domestic cats, respectively. Gray heavy lines indicate hiking trails. 
Table 1. Information on the microsatellite loci used for genotyping red foxes on Mt. Hakodate

\begin{tabular}{|c|c|c|c|c|c|c|}
\hline Locus & Fluorescent label & $\begin{array}{l}\text { Primer mix } \\
\text { combination }^{\mathrm{a}}\end{array}$ & Allele size (bp) & Number of alleles & $\begin{array}{c}\text { Genotyping } \\
\text { success rate }(\%)\end{array}$ & Reference $^{\mathrm{b}}$ \\
\hline DB1 & 6-FAM & A & $130-152$ & 4 & 79.0 & 1 \\
\hline DB3 & VIC & $\mathrm{C}$ & $125-131$ & 3 & 81.5 & 1 \\
\hline DB4 & PET & $\mathrm{B}$ & $112-118$ & 3 & 77.3 & 1 \\
\hline DB6 & 6-FAM & $\mathrm{C}$ & $106-112$ & 4 & 70.6 & 1 \\
\hline V142 & NED & $\mathrm{C}$ & $136-150$ & 4 & 74.8 & 2 \\
\hline V374 & NED & A & 105 & 1 & 79.8 & 2 \\
\hline V402 & VIC & $\mathrm{B}$ & $81-85$ & 3 & 84.0 & 2 \\
\hline V468 & PET & A & $87-91$ & 3 & 81.5 & 2 \\
\hline V602 & 6-FAM & $\mathrm{B}$ & $137-147$ & 2 & 77.3 & 2 \\
\hline Mean & & & & 3.0 & 78.4 & \\
\hline
\end{tabular}

${ }^{a}$ Letters indicate combinations of primers included in the same mix.

${ }^{b}$ References: 1, Lade et al. (1996); 2, Wandeler and Funk (2006).

following 10 microsatellite loci were selected for amplification: DB1, DB3, DB4, and DB6 (Lade et al. 1996), and V142, V374, V402, V468, V602, and V622 (Wandeler and Funk 2006). Locus V622 was later excluded because no PCR amplification was obtained for the locus. The 5' end of each forward primer was fluorescently labeled with 6-FAM ${ }^{\mathrm{TM}}$, NED ${ }^{\mathrm{TM}}, \mathrm{VIC}^{\circledR}$, or $\mathrm{PET}^{\mathrm{TM}}$ (Applied Biosystems). PCR amplifications were performed with the QIAGEN Multiplex PCR Kit (Qiagen) and a TP600 DNA thermal cycler (Takara). Reactions were done in $5.0 \mu \mathrm{l}$ volumes each containing $2.5 \mu \mathrm{l}$ of $2 \times$ QIAGEN Multiplex PCR Master Mix, $0.9 \mu \mathrm{l}$ of RNase-free water, $0.5 \mu \mathrm{l}$ of primer mix ( $2.0 \mu \mathrm{M}$ each primer) containing the forward and reverse primers for three loci, $0.1 \mu \mathrm{l}$ of bovine serum albumin (BSA) solution ( $20 \mathrm{mg} / \mathrm{ml}$, Roche), and $1.0 \mu \mathrm{l}$ of template DNA. PCR thermal conditions were $95^{\circ} \mathrm{C}$ for $15 \mathrm{~min} ; 35$ cycles of $94^{\circ} \mathrm{C}$ for $30 \mathrm{sec}, 57^{\circ} \mathrm{C}$ for $90 \mathrm{sec}$ and $72^{\circ} \mathrm{C}$ for $1 \mathrm{~min}$; and $60^{\circ} \mathrm{C}$ for $30 \mathrm{~min}$. Primer mix combinations are given in Table 1 . PCR products were subjected to electrophoresis in an ABI3730 DNA sequencer (Applied Biosystems), and molecular sizes were then measured with Peak Scanner 1.0 (Applied Biosystems) to determine alleles and genotypes.

For genotyping, each locus was amplified by PCR at least three times. Samples were considered homozygous for a locus when only one allele was detected for that locus in three amplifications. In cases when a PCR reaction detected two alleles for a locus in a particular sample, the locus was judged to be heterozygous only after the two alleles were detected in at least one additional independent PCR for the sample. Samples that yielded no PCR products for five or more loci were excluded from subsequent analyses.
To assess how many markers were sufficient to distinguish between different individuals using data from fecal samples, the probabilities of identity for unrelated individuals $\left(P_{\mathrm{ID}}\right)$ and siblings $\left(P_{\mathrm{ID}-\mathrm{sibs}}\right)$ (Waits et al. 2001) were calculated with the program GIMLET 1.3.3 (Valière 2002). Mills et al. (2000) recommended a $P_{\mathrm{ID}}$ less than approximately 0.01 for estimating population size.

\section{Individual identification and population size/density estimation}

Determined genotypes were grouped by individuals with the program GIMLET 1.3.3. Population sizes of adults (one year of age and older) were inferred from three-year follow-up data based on individual identification. Individuals observed for a multi-year period were assumed to be adults, and were utilized to estimate population sizes. In contrast, individuals observed in a singleyear were assumed to be young or adult. Based on this inferred population sizes, population densities were calculated from the area of the mountain (326 ha) assumed.

\section{Sexing using the $Z F X$ and $Z F Y$ genes}

To determine the sex of red fox individuals from fecal samples more easily, we designed three new sex-specific primers based on partial sequences from each of the $\mathrm{X}$ and Y chromosomes, with which PCR fragments shorter than those in the previous studies (Ortega et al. 2004; Moore et al. 2010) were amplified: VVZFX-F1 (5'-TGA AGT TTT CAG ACC AGG GTT C-3'), VVZFY-F1 (5'-GGG TTT TTC TGT TAC CTC TTT TG-3') and VVZFYX-R1 (5'-CAT GAG TGA TCA AAC CAA GTT C-3'). These primers were designed based on the part of 
the final intron sequence of the zinc-finger coding gene on the $\mathrm{X}(Z F X)$ and $\mathrm{Y}(Z F Y)$ chromosomes (GenBank accession numbers AB622129 and AB622140, Tsubouchi et al. 2012). PCR reactions were performed in $20 \mu$ volumes each containing $0.2 \mu \mathrm{l}$ of TaKaRa Taq ${ }^{\mathrm{TM}}$ DNA polymerase (5 U/ $\mu$ l, Takara), $2.0 \mu \mathrm{l}$ of $10 \times$ PCR buffer, $1.6 \mu \mathrm{l}$ of dNTP mixture (2.5 mM each), $0.4 \mu 1$ of BSA solution $(20 \mathrm{mg} / \mathrm{ml}$, Roche), $0.2 \mu \mathrm{l}$ of each primer $(2.5 \mu \mathrm{M}), 1.0 \mu \mathrm{l}$ of each DNA extract, and $14.4 \mu \mathrm{l}$ of distilled water. PCR thermal conditions were $94^{\circ} \mathrm{C}$ for $5 \mathrm{~min} ; 35$ cycles of $94^{\circ} \mathrm{C}$ for $30 \mathrm{sec}, 56^{\circ} \mathrm{C}$ for $30 \mathrm{sec}, 72^{\circ} \mathrm{C}$ for $1 \mathrm{~min}$; and $72^{\circ} \mathrm{C}$ for $10 \mathrm{~min}$. PCR products were subjected to electrophoresis on a $3 \%$ agarose gel and visualized with ethidium bromide under an ultraviolet illuminator. These primers gave PCR products of $100 \mathrm{bp}$ for $Z F X$ and $131 \mathrm{bp}$ for $Z F Y$ (Appendix 1), with one band and two bands indicating female and male, respectively. For confirmation, PCRs to determine sex were performed at least twice for each sample. The source of a sample was judged to be a male if at least two PCR amplifications showed both the $Z F X$ and $Z F Y$ fragments, and to be a female if at least three PCR amplifications showed only the $Z F X$ fragment, with no amplification of the $Z F Y$ fragment.

\section{Data analyses}

The genetic diversity and structure of the Mt. Hakodate population were compared with those of other populations on Hokkaido by using the microsatellite data of Oishi et al. (2011). The population structure was analyzed with STRUCTURE 2.3.4 (Pritchard et al. 2000). Ten runs were performed for each number of genetic clusters $(K)$ from 1 to 10. Each run consisted of 1000 Markov Chain Monte Carlo (MCMC) iterations after a burn-in of 1000 iterations. To determine the most likely $K, \Delta K$ values were estimated by using STRUCTURE HARVESTER (Earl and vonHoldt 2012). The degree of genetic divergence between populations (pairwise $F_{\text {ST }}$ ) was estimated by using ARLEQUIN 3.5.1.2 (Excoffier and Lischer 2010). A population network based on $F_{\text {ST }}$ values was constructed with the neighbor joining method in MEGA 6 (Tamura et al. 2013).

The effective population sizes $\left(N_{\mathrm{e}}\right)$ based on linkage disequilibrium (Waples and Do 2008) were calculated for the Mt. Hakodate and SOP populations by using NeEstimator 2.01 (Do et al. 2014). The mean numbers of alleles $(A)$, observed and expected heterozygosity $\left(H_{\mathrm{O}}\right.$ and $H_{\mathrm{E}}$, respectively), and inbreeding coefficient $\left(F_{\mathrm{IS}}\right)$ were calculated and tested by using ARLEQUIN 3.5.1.2
(Excoffier and Lischer 2010). Allelic richness $\left(A_{\mathrm{R}}\right)$, normalized to the smallest number of samples, was calculated by using FSTAT 2.9.3.2 (Goudet 2002). Significance tests for $F_{\text {IS }}$ values were performed by using HardyWeinberg exact test implemented in GENEPOP 4.2 (Raymond and Rousset 1995; Rousset 2008).

\section{Results}

\section{Species identification}

During the entire investigation, total 150 samples (49 in 2009, 48 in 2010, and 53 in 2011) of feces were collected on Mt. Hakodate, and species identification by PCR amplification of mtDNA fragments was successful for $122(81.3 \%)$ of them (Table 2). The red fox was identified as the source of $98(65.3 \%)$ of the samples, and the domestic cat as the source of 16 samples (10.7\%). In addition, mtDNA fragments from both the red fox and the domestic cat were amplified from eight $(5.3 \%)$ of the samples. From the remaining 28 samples (18.7\%), no mtDNA fragments were amplified from the red fox, domestic cat, or domestic dog. The locations of samples identified as the red fox or domestic cat are shown in Fig. 1C. All six fecal samples obtained in places other than Mt. Hakodate were identified as the red fox, and were used for comparisons among populations.

\section{Individual identification and population size/density estimation}

The genotyping success rate per locus ranged from $70.6 \%$ to $84.0 \%$ (average, $78.4 \%$ ), and $1-4$ (average, 3.0 ) alleles were detected per locus (Table 1). The cumulative $P_{\mathrm{ID}-\text { sibs }}$ and $P_{\mathrm{ID}}$ values for the nine loci examined were 0.015 and less than 0.001 , respectively (Appendix 2), with the cumulative $P_{\text {ID-sibs }}$ value only slightly larger than the value of 0.01 recommended for estimating population size. The genotype data permitted individual identifica-

Table 2. Frequencies of identification of fecal samples to species, using species-specific primers

\begin{tabular}{|c|c|c|c|c|}
\hline & 2009 & 2010 & 2011 & 2009-2011 \\
\hline Red fox & $31(63.3 \%)$ & $25(52.1 \%)$ & $42(79.2 \%)$ & $98(65.3 \%)$ \\
\hline $\begin{array}{l}\text { Red fox }+ \\
\text { Domestic cat }\end{array}$ & $3(6.1 \%)$ & $2(4.2 \%)$ & $3(5.7 \%)$ & $8 \quad(5.3 \%)$ \\
\hline Domestic cat & $4 \quad(8.2 \%)$ & $6(12.5 \%)$ & $6(11.3 \%)$ & $16(10.7 \%)$ \\
\hline Domestic dog & $0 \quad(0.0 \%)$ & $0 \quad(0.0 \%)$ & $0 \quad(0.0 \%)$ & $0 \quad(0.0 \%)$ \\
\hline Not amplified & $11(22.4 \%)$ & $15(31.3 \%)$ & $2(3.8 \%)$ & $28(18.7 \%)$ \\
\hline Total & 49 & 48 & 53 & 150 \\
\hline
\end{tabular}


Table 3. Number of fecal samples identified and sex or 35 red fox individuals identified in this study

\begin{tabular}{|c|c|c|c|c|c|}
\hline \multirow{2}{*}{$\begin{array}{l}\text { Individual } \\
\text { ID }\end{array}$} & \multirow{2}{*}{$\begin{array}{l}N_{\text {obs }} \text { for the } \\
\text { entire period }\end{array}$} & \multicolumn{3}{|c|}{$N_{\text {obs }}$ per year } & \multirow{2}{*}{ Sex } \\
\hline & & 2009 & 2010 & 2011 & \\
\hline MH01 & 7 & 2 & 5 & & M \\
\hline MH02 & 10 & 8 & 1 & 1 & $\mathrm{~F}$ \\
\hline MH03 & 8 & 3 & 1 & 4 & F \\
\hline MH04 & 1 & 1 & & & $\mathrm{U}$ \\
\hline MH05 & 6 & 3 & 3 & & F \\
\hline MH06 & 1 & 1 & & & M \\
\hline MH07 & 1 & 1 & & & $\mathrm{~F}$ \\
\hline MH08 & 2 & 2 & & & F \\
\hline MH09 & 2 & 1 & & 1 & M \\
\hline MH10 & 1 & 1 & & & $\mathrm{~F}$ \\
\hline MH11 & 1 & 1 & & & $\mathrm{~F}$ \\
\hline MH12 & 6 & 1 & & 5 & M \\
\hline MH13 & 3 & & 3 & & M \\
\hline MH14 & 1 & & 1 & & M \\
\hline MH15 & 1 & & 1 & & M \\
\hline MH16 & 2 & & 1 & 1 & M \\
\hline MH17 & 1 & & 1 & & M \\
\hline MH18 & 1 & & 1 & & F \\
\hline MH19 & 4 & & 1 & 3 & M \\
\hline MH20 & 3 & & & 3 & M \\
\hline MH21 & 3 & & & 3 & M \\
\hline MH22 & 2 & & & 2 & $\mathrm{~F}$ \\
\hline MH23 & 1 & & & 1 & M \\
\hline MH24 & 1 & & & 1 & $\mathrm{U}$ \\
\hline MH25 & 1 & & & 1 & $\mathrm{~F}$ \\
\hline MH26 & 1 & & & 1 & $\mathrm{~F}$ \\
\hline MH27 & 4 & & & 4 & M \\
\hline МH28 & 1 & & & 1 & $\mathrm{U}$ \\
\hline МH29 & 1 & & & 1 & F \\
\hline МH30 & 1 & & & 1 & $\mathrm{U}$ \\
\hline MH31 & 1 & & & 1 & $\mathrm{U}$ \\
\hline MH32 & 3 & & & 3 & $\mathrm{~F}$ \\
\hline MH33 & 1 & & & 1 & M \\
\hline MH34 & 1 & & & 1 & M \\
\hline MH35 & 1 & & & 1 & M \\
\hline Total $N_{\text {obs }}$ & 85 & 25 & 19 & 41 & $\mathrm{M} 40 / \mathrm{F} 35 / \mathrm{U} 10$ \\
\hline Mean $N_{\text {obs }}$ & 2.4 & 2.1 & 1.7 & 1.9 & \\
\hline Total $N_{\text {ind }}$ & 35 & 12 & 11 & 22 & M17/F13/U5 \\
\hline
\end{tabular}

$N_{\text {obs, }}$, number of fecal samples per individual; M, male; F, female; $\mathrm{U}$, sex unknown; $N_{\text {ind }}$, total number of individuals. Shaded cells indicate time spans when an individual is confirmed as alive.

tion of 85 fecal samples for the three years ( 25 in 2009, 19 in 2010, and 41 in 2011), which were derived from 35 foxes (12 in 2009, 11 in 2010, and 22 in 2011) (Table 3). Of them, eight foxes (MH01, MH02, MH03, MH05, MH09, MH12, MH16, and MH19) were observed for a multi-year period (i.e., individuals expected to be adult), and 11 foxes (MH04, MH06, MH07, MH08, MH10, MH11, MH13, MH14, MH15, MH17, and MH18) except foxes firstly observed for 2011 were observed only in a single-year (i.e., individuals expected to be juvenile). In both 2010 and 2011, the population size and density of adult foxes were estimated to be six (MH01, MH02, MH03, MH05, MH09, and MH12 in 2010; MH02, MH03, MH09, MH12, MH16, and MH19 in 2011) and 1.8 adult foxes $/ \mathrm{km}^{2}$, respectively.

\section{Sex identification}

Among the red fox 85 fecal samples identified individually, 40 samples came from males and 35 from females; sex could not be determined for the remaining 10 samples (Table 3). Sex was successfully determined for 30 of 35 individuals; these 30 individuals comprised 17 males and 13 females. Sex mismatch was not found among multiple fecal samples from the same individuals.

\section{Genetic structure and diversity}

Fig. 2 shows the genetic structure of the entire Hokkaido population including the population on Mt. Hakodate. The highest $\Delta K$ was calculated to be two (Appendix 3), indicating that the populations in southern Hokkaido, including the Mt. Hakodate and SOP populations, are separated from those in the rest of Hokkaido. The STRUCTURE analysis at $K \geq 4$ showed the population structure on Mt. Hakodate to be clearly different from that in Southern Hokkaido. Additionally, the red fox population on Mt. Hakodate was relatively homogeneous, indicating low genetic variation in this population. Genetic differentiation between the Mt. Hakodate population and other populations was also indicated by higher $F_{\mathrm{ST}}$ values (Fig. 3), which ranged from 0.13 to 0.16 between Mt. Hakodate and the other populations except the SOP population (Table 4 ), whereas $F_{\text {ST values among }}$ other populations except the Mt. Hakodate population ranged from 0.00 to 0.12 (data not shown).

Table 5 shows barometers of the genetic diversity in the red fox populations on Hokkaido. The effective population size for the Mt. Hakodate population was 6.7 although that for the SOP population was infinite. The values for the mean number of alleles $(A)$, allelic richness $\left(A_{\mathrm{R}}\right)$, and observed and expected heterozygosities $\left(H_{\mathrm{O}}\right.$ and $\left.H_{\mathrm{E}}\right)$ in the Mt. Hakodate population were lower than those in the SOP population and in the other populations on Hokkaido $\left(A=5.000-8.375, A_{\mathrm{R}}=3.612-4.061, H_{\mathrm{E}}=\right.$ $0.625-0.671, H_{\mathrm{O}}=0.588-0.660$, not shown in the table). Significant heterozygote deficiency (i.e., deviations from 


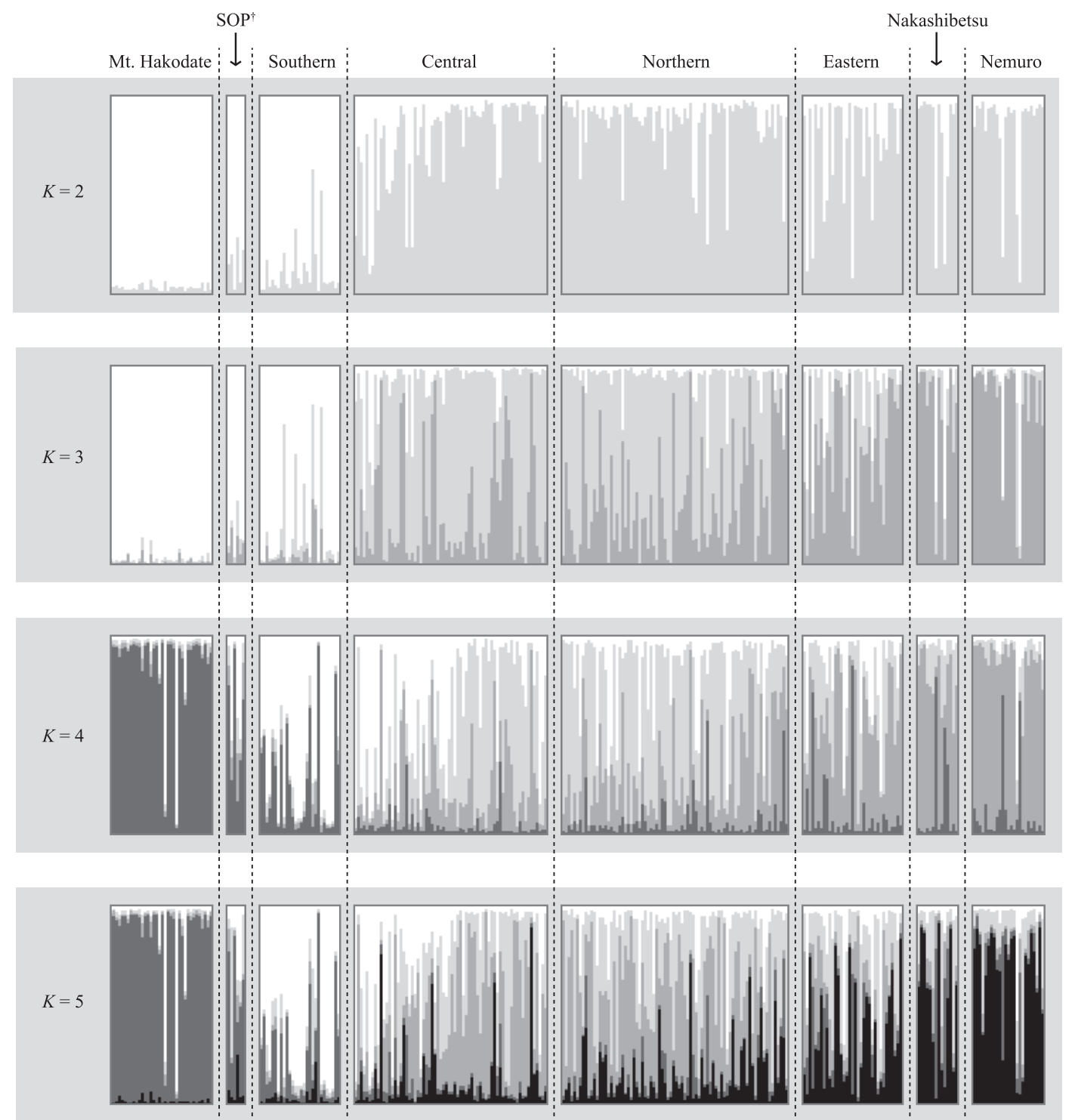

Fig. 2. Results of a STRUCTURE analysis $(K=2-5)$ of the Mt. Hakodate population and the other red fox populations in Hokkaido. The microsatellite data of Southern, Central, Eastern, Nakashibetsu, and Nemuro populations were cited from Oishi et al. (2011). $\dagger$, the southern part of the Oshima Peninsula.

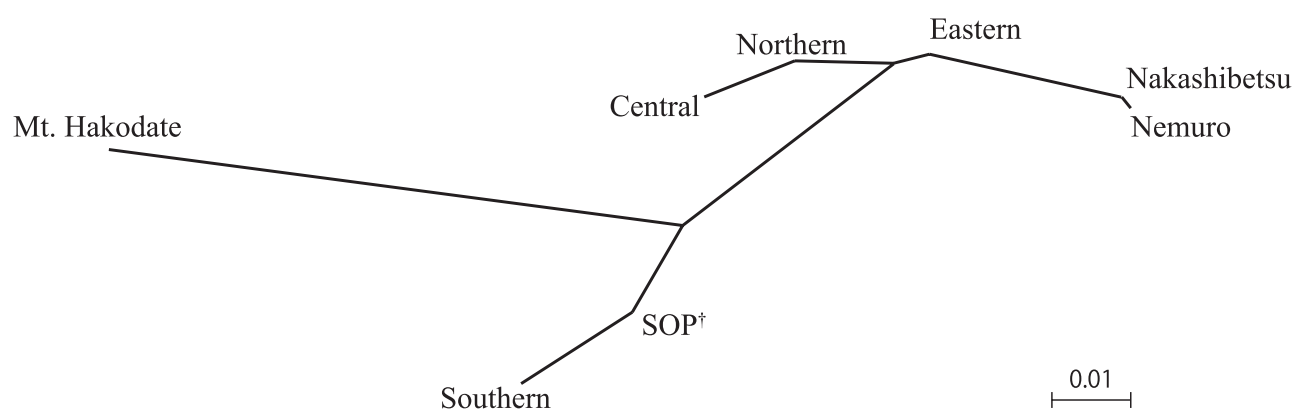

Fig. 3. Network of fox populations in Hokkaido, based on $F_{\mathrm{ST}}$ values from parwise comparisons between populations. The microsatellite data of Southern, Central, Northern, Eastern, Nakashibetsu, and Nemuro populations were cited from Oishi et al. (2011). †, the southern part of the Oshima Peninsula. 
Table 4. Pairwise $F_{\mathrm{ST}}$ values among red fox populations in Hokkaido, based on microsatellite data from Mt. Hakodate and the southern part of the Oshima Peninsula (SOP) (this study) and from other populations (Oishi et al. 2011)

\begin{tabular}{lccccccc}
\hline & SOP & Southern & Central & Northern & Eastern & Nakashibetsu & Nemuro \\
\hline Mt. Hakodate & $0.08^{* *}$ & $0.14^{* * *}$ & $0.16^{* * *}$ & $0.15^{* * *}$ & $0.13^{* * *}$ & $0.15^{* * *}$ & $0.16^{* * *}$ \\
SOP & - & $0.01^{\mathrm{ns}}$ & $0.09^{* * *}$ & $0.07^{* * *}$ & $0.06^{* * *}$ & $0.07^{* * *}$ & $0.09^{* * *}$ \\
\hline
\end{tabular}

Significance of the $F_{\mathrm{ST}}$ values: ***, $P<0.001 ; * *, P<0.01 ; *, P<0.05 ;$ ns, not significant.

Table 5. Microsatellite variation in the Mt. Hakodate and SOP populations

\begin{tabular}{lrccccccc}
\hline Populations & $N$ & $N_{\mathrm{e}}(C I)$ & $A$ & $A_{\mathrm{R}}$ & $H_{\mathrm{E}}$ & $H_{\mathrm{O}}$ & $F_{\mathrm{IS}}$ \\
\hline Mt. Hakodate & 36 & $6.7(3.2-13.1)$ & 3.250 & 2.592 & 0.476 & 0.454 & 0.047 & 0.004 \\
SOP & 6 & $\infty(14.6-\infty)$ & 3.500 & 3.409 & 0.618 & 0.596 & 0.043 & 0.447 \\
\hline
\end{tabular}

$N$, number of individuals; $N_{\mathrm{e}}$, effective population size; $C I, 95 \%$ confidence interval for $N_{\mathrm{e}} ; A$, mean number of alleles; $A_{\mathrm{R}}$, allelic richness; $H_{\mathrm{E}}$, expected heterozygosity; $H_{\mathrm{O}}$, observed heterozygosity; $F_{\mathrm{IS}}$, inbreeding coefficient; $P, P$ value for $F_{\mathrm{IS}}$.

Hardy-Weinberg equilibrium) was detected in the Mt. Hakodate population $\left(F_{\mathrm{IS}}=0.047, P<0.05\right)$ although it was not detected in the SOP population $\left(F_{\mathrm{IS}}=0.043\right.$, $P>0.05)$.

\section{Discussion}

Species composition and monitoring based on noninvasive genetic samples

Some previous studies have briefly surveyed other wild animal populations, including the red fox, using noninvasive genetic samples as in our study (Fernandes et al. 2008; Shimatani et al. 2008; Statham et al. 2012). Other, more extensive studies have used noninvasive samples to monitor species or individual distributions, population size, and genetic diversity across multiple years in various species, including the gray wolf (C. lupus) (Stenglein et al. 2010; Stansbury et al. 2014), San Joaquin kit fox (V. macrotis mutica) (Wilbert et al. 2015), Amur tiger (Panthera tigris) (Sugimoto et al. 2012), Far Eastern leopard (P. pardus orientalis) (Sugimoto et al. 2013), and sable (Martes zibellina) (Nagai et al. 2014), but there has been no similar previous study on the red fox.

Our study using fecal DNA revealed that both the red fox and domestic cat inhabit Mt. Hakodate. It is unclear whether the cats are feral, or are pets wandering from nearby residential areas. It is also unclear why DNA from both species was occasionally detected in single fecal samples. This might result from one of the species marking territory by defecating in the same place, or from foxes preying on cats, and in fact, Contesse et al. (2004) found cat remains in stomach contents of red foxes.
Success rate of species detection and genotyping

The amplification rate of mtDNA fragments $(81.3 \%)$ in species identification in our study was within the range of approximately $60-96 \%$ in previous studies using fecal DNA from wild carnivorans (Kurose et al. 2005; Sugimoto et al. 2006; Shimatani et al. 2008). However, our success rates (70.6-84.0\%; average, $78.4 \%)$ for genotyping microsatellite loci were high. Oishi et al. (2010) determined genotypes with success rates of $23.3-69.8 \%$ per locus in individual identification of red foxes in the Shiretoko National Park, Hokkaido. Nagai et al. (2014) genotyped sables in eastern Hokkaido with success rates of $47.8-76.1 \%$ per locus (average, 63.6\%). Our high success rates were likely due to a high frequency of sampling and the method used to preserve fecal samples. We conducted sampling at least once a month and thus obtained relatively fresh feces. This was an important factor, because it is difficult to amplify microsatellite DNA from fecal samples that have remained in the open for more than three months (Piggott 2004). Furthermore, we preserved fecal samples by freezing, which according to some studies gives a higher genotyping success rate under specific conditions than samples preserved in ethanol (Piggott and Taylor 2003; Santini et al. 2007). Finally, for freezing samples we used a $-80^{\circ} \mathrm{C}$ ultracold freezer rather than the standard $-20^{\circ} \mathrm{C}$ freezer generally used for sample preservation.

\section{Small population size}

Our study showed that at least 11-22 (annual average, 15) foxes per year actually inhabited Mt. Hakodate, and indicated that the population size is small. However, the population size we estimated in this study could contain 
the number of young foxes under one year old, which have high mortality (Yoneda and Maekawa 1982). In fact, the number of foxes observed only in a single-year (i.e., individuals expected to be juvenile) was larger than that of foxes observed for a multi-year period (i.e., individuals expected to be adult). Additionally, the adult population sizes (six adult foxes/year) inferred from the follow-up data were as small as the effective population size $\left(N_{\mathrm{e}}=\right.$ 6.7), and correspond to up to three families if the sex ratio was equal. The numbers of adults of both sexes (three males and three females) assumed in 2010 might support that. This result indicated that the actual population size of foxes on Mt. Hakodate might be extremely small. On the other hand, the population densities estimated based on the putative numbers of adult foxes (1.8 adult foxes $/ \mathrm{km}^{2}$ ) corresponds to rural level in comparison to typical densities $\left(0.2-2.7\right.$ and $2-12$ adult foxes $/ \mathrm{km}^{2}$ in rural and urban areas, respectively; Soulsbury et al. 2010). However, this estimation might be underestimated due to undetected individuals.

The number of individuals successfully genotyped in 2011 was largest for the three years. It is not necessarily appropriate to suggest that the number of individuals reflect the abundance because the rate of species identification is not equal throughout the years. Small proportion of unamplified samples in 2011 might be attributed to obtainment of better samples, short storage to DNA extraction, and improvement in laboratory technique.

\section{Isolation by urban areas}

Our microsatellite data compared with the data of Oishi et al. (2011) indicated that the genetic structure in the Mt. Hakodate population was greatly different from those of the other populations in Hokkaido, which means that the Mt. Hakodate population becomes geographically isolated from other populations by the urban development of Hakodate City. Although red foxes can disperse up to $302 \mathrm{~km}$ in straight-line distance (Allen and Sargeant 1993), the dense Hakodate urban area, which separates Mt. Hakodate from the rest of the Kameda Peninsula by only $8.5 \mathrm{~km}$, likely inhibits gene flow between the two areas, and this has resulted in inbreeding on Mt. Hakodate. However, the Mt. Hakodate population has two individuals assigned to the Southern population. This indicates that foxes might fairly infrequently immigrate to Mt. Hakodate through the urban area or that major alleles in the Southern population might remain as a minor allele in the Mt. Hakodate population. The Mt. Hakodate population must have been a part of the south- ern Oshima Peninsula population before development of the city, as our results show that the genetic structure of both populations are similar to each other.

\section{Low genetic diversity}

As our hypothesis, our microsatellite data indicated that the genetic diversity in the Mt. Hakodate population was low compared with those of the other populations in Hokkaido. The low genetic diversity we detected was corroborated by the $P_{\mathrm{ID}}$ values, which not only indicate the statistical confidence in individual identification but also are inversely correlated with the level of genetic diversity in natural populations (Paetkau and Strobeck 1994; Paetkau et al. 1998). The genetic diversity of the Mt. Hakodate population appears to be lower than that of the restricted population in the Shiretoko National Park, eastern Hokkaido, because the cumulative $P_{\mathrm{ID}-\text { sib }}$ in a study there by Oishi et al. (2010) was less than 0.01 at the seventh locus in only 22 samples, whereas in our study $P_{\text {ID-sib }}$ was greater than 0.01 at the ninth locus in 36 samples, even though we used nearly the same microsatellite makers.

Our statistical results showed that deviations from Hardy-Weinberg equilibrium occurred in the Mt. Hakodate population. This indicates a small number of individuals, no random mating, and/or inbreeding in the population.

\section{Formation process of the isolated population}

As a conclusion of the present study, the Mt. Hakodate population geographically isolated has a low genetic diversity, which is due to gene flow restricted by the urban area of Hakodate City and the small population size leading to inbreeding and genetic drift. We then discussed the background in detail in the light of historical phenomena.

A possible scenario for how the Mt. Hakodate population became genetically isolated is as follows. Mt. Hakodate was an island previous to about 5000 years ago (Ganzawa 2002), when it became connected to the Hokkaido mainland. The red fox probably colonized Mt. Hakodate after that time, and could have moved freely between Mt. Hakodate and the rest of the Kameda Peninsula (Fig. 1B). At this early stage, some alleles were restricted to red foxes inhabiting the Kameda Peninsula. From the Meiji period (1868-1912), the city of Hakodate developed on the land bridge connecting Mt. Hakodate and rapidly increased in population (Nemoto 1990), resulting in a gradual decrease in gene flow between foxes on Mt. Hakodate and those on the rest of the Kameda 
Peninsula. Isolation, genetic drift, and inbreeding could then have led to the present genetic structure unique to Mt. Hakodate.

Acknowledgments: We thank Mr. Takuya Oishi for assistance with data analysis and Dr. Matthew Dick for useful comments and editing the manuscript. This study was supported in part by the Akiyama Life Science Foundation.

\section{References}

Allen, S. H. and Sargeant, A. B. 1993. Dispersal patterns of red foxes relative to population density. Journal of Wildlife Management 57: 526-533.

Berry, O., Sarre, S. D., Farrington, L. and Aitken, N. 2007. Faecal DNA detection of invasive species: the case of feral foxes in Tasmania. Wildlife Research 34: 1-7.

Contesse, P., Hegglin, D., Gloor, S., Bontadina, F. and Deplazes, P. 2004. The diet of urban foxes (Vulpes vulpes) and the availability of anthropogenic food in the city of Zurich, Switzerland. Mammalian Biology 69: 81-95.

Dallas, J. F., Coxon, K. E., Sykes, T., Chanin, P. R. F., Marshall, F., Carss, D. N., Bacon, P. J., Piertney, S. B. and Racey, P. A. 2003. Similar estimates of population genetic composition and sex ratio derived from carcasses and faeces of Eurasian otter Lutra lutra. Molecular Ecology 12: 275-282.

Do, C., Waples, R. S., Peel, D., Macbeth, G. M., Tillett, B. J. and Ovenden, J. R. 2014. NeEstimator v2: re-implementation of software for the estimation of contemporary effective population size $\left(N_{e}\right)$ from genetic data. Molelular Ecology Resource 14: 209214.

Earl, D. A. and vonHoldt, B. M. 2012. STRUCTURE HARVESTER: a website and program for visualizing STRUCTURE output and implementing the Evanno method. Conservation Genetics Resources 4: 359-361.

Excoffier, L. and Lischer, H. E. L. 2010. Arlequin suite ver 3.5: a new series of programs to perform population genetics analyses under Linux and Windows. Molecular Ecology Resources 10: 564-567.

Fernandes, C. A., Ginja, C., Pereira, I., Tenreiro, R., Bruford, M. W. and Santos-Reis, M. 2008. Species-specific mitochondrial DNA markers for identification of non-invasive samples from sympatric carnivores in the Iberian Peninsula. Conservation Genetics 9: $681-690$

Frankham, R. 2010. Challenges and opportunities of genetic approaches to biological conservation. Biological Conservation 143: 19191927.

Furlan, E., Stoklosa, J., Griffiths, J., Gust, N., Ellis, R., Huggins, R. M. and Weeks, A. R. 2012. Small population size and extremely low levels of genetic diversity in island populations of the platypus, Ornithorhynchus anatinus. Ecology and Evolution 2: 844-857.

Ganzawa, N. 2002. Hakodate City: Mt. Hakodate, great observatory of nature. In (The Southern Hokkaido Group of the Association for the Geological Collaboration, ed.) Donan No Shizen Wo Aruku, Revised edition, pp. 2-13. Hokkaido University Press, Sapporo (in Japanese).

Goudet, J. 2002. FSTAT: a program to estimate and test gene diversities and fixation indices (Version 2.9.3.2). Available at http://www. unil.ch/izea/softwares/fstat.html (Accessed 26 January 2015).
Hakodate City. 2016. Hakodate-Shi Kankyo Hakusho (White Paper on Environment in Hakodate City). Hakodate City Environment Administration Section of Environment Department, Hakodate, 126 pp. (in Japanese).

Kimura, M. 2011. Shizen Gaido Hakodate Yama (Nature Guide of Mt. Hakodate). The Hokkaido Shimbun Press, Sapporo, 112 pp. (in Japanese).

Kohyama, T. I., Omote, K., Nishida, C., Takenaka, T., Saito, K., Fujimoto, S. and Masuda, R. 2015. Spatial and temporal variation at major histocompatibility complex class IIB genes in the endangered Blakiston's fish owl. Zoological Letters 1: 13. DOI: 10.1186/ s40851-015-0013-4.

Kurose, N., Masuda, R. and Tatara, M. 2005. Fecal DNA analysis for identifying species and sex of sympatric carnivores: a noninvasive method for conservation on the Tsushima Islands, Japan. Journal of Heredity 96: 688-697.

Lade, J. A., Murray, N. D., Marks, C. A. and Robinson, N. A. 1996. Microsatellite differentiation between Phillip Island and mainland Australian populations of the red fox Vulpes vulpes. Molecular Ecology 5: 81-87.

Macdonald, D. W. and Reynolds, J. C. 2008. Vulpes vulpes. In the IUCN Red List of Threatened Species 2008: e.T23062A9412884 Available at http://dx.doi.org/10.2305/IUCN.UK.2008.RLTS. T23062A9412884.en (Accessed 22 April 2016).

Mills, L. S., Citta, J. J., Lair, K. P., Schwartz, M. K. and Tallmon, D. A. 2000. Estimating animal abundance using noninvasive DNA sampling: promise and pitfalls. Ecological Applications 10: 283-294.

Moore, M., Brown, S. and Sacks, B. 2010. Thirty-one short red fox (Vulpes vulpes) microsatellite markers. Molecular Ecology Resources 10: 404-408.

Munakata, H. 1980. Seibutu no bunpu (Disribution of organisms). In (Hakodate City Office, ed.) Hakodate-Shi Shi: Tsusetsu-Hen (History of Hakodate City: Regular History Series), Vol. 1. pp. 59-86. Hakodate City Office, Hakodate (in Japanese).

Nagai, T., Murakami, T. and Masuda, R. 2014. Effectiveness of noninvasive DNA analysis to reveal isolated-forest use by the sable Martes zibellina on eastern Hokkaido, Japan. Mammal Study 39: 99-104.

Nemoto, N. 1990. Toshi keisei to sono kouzo (City formation and structure). In (Hakodate-shi shi hensan shitsu (Compilation room of history of Hakodate City), ed.) Hakodate-Shi Shi: Tsusetsu-Hen (History of Hakodate City: Regular History Series), Vol. 2. pp. 459-560. Hakodate City Office, Hakodate (in Japanese).

Nims, B. D., Vargas, F. H., Merkel, J. and Parker, P. G. 2008. Low genetic diversity and lack of population structure in the endangered Galápagos penguin (Spheniscus mendiculus). Conservation Genetics 9: 1413-1420.

Oishi, T., Uraguchi, K. and Masuda, R. 2010. Non-invasive genetic identification of the red fox Vulpes vulpes in the Shiretoko National Park, eastern Hokkaido, Japan. Mammal Study 35: 201-207.

Oishi, T., Uraguchi, K., Takahashi, K. and Masuda, R. 2011. Population structures of the red fox (Vulpes vulpes) on the Hokkaido Island, Japan, revealed by microsatellite analysis. Journal of Heredity 102: 38-46.

Ortega, J., Franco, M. d. R., Adams, B. A., Ralls, K. and Maldonado, J. E. 2004. A reliable, non-invasive method for sex determination in the endangered San Joaquin kit fox (Vulpes macrotis mutica) and other canids. Conservation Genetics 5: 715-718.

Paetkau, D. and Strobeck, C. 1994. Microsatellite analysis of genetic variation in black bear populations. Molecular Ecology 3: 489495.

Paetkau, D., Waits, L. P., Clarkson, P. L., Craighead, L., Vyse, E., Ward, 
R. and Strobeck, C. 1998. Variation in genetic diversity across the range of North American brown bears. Conservation Biology 12: 418-429.

Paradiso, J. L. and Handley, C. O. 1965. Checklist of mammals of Assateague Island. Chesapeake Science 6: 167-171.

Piggott, M. P. 2004. Effect of sample age and season of collection on the reliability of microsatellite genotyping of faecal DNA. Wildlfe Research 31: 485-493.

Piggott, M. P. and Taylor, A. C. 2003. Extensive evaluation of faecal preservation and DNA extraction methods in Australian native and introduced species. Australian Journal of Zoology 51: 341-355.

Pritchard, J. K., Stephens, M. and Donnelly, P. 2000. Inference of population structure using multilocus genotype data. Genetics 155: 945-959.

QGIS Development Team. 2011. GIS Geographic Information System. Available at http://www.qgis.org/ (Accessed 9 February 2016).

Raymond, M. and Rousset, F. 1995. GENEPOP (version 1.2): population genetics software for exact tests and ecumenicism. Journal of Heredity 86: 248-249.

Rousset, F. 2008. Genepop'007: a complete reimplementation of the Genepop software for Windows and Linux. Molecular Ecology Resources 8: 103-106.

Saito, W., Amaike, Y., Sako, T., Kaneko, Y. and Masuda, R. 2016. Population structure of the raccoon dog on the grounds of the Imperial Palace, Tokyo, revealed by microsatellite analysis of fecal DNA. Zoological Science 33: 485-490.

Santini, A., Lucchini, V., Fabbri, E. and Randi, E. 2007. Ageing and environmental factors affect PCR success in wolf (Canis lupus) excremental DNA samples. Molecular Ecology Notes 7: 955-961.

Shimatani, Y., Takeshita, T., Tatsuzawa, S., Ikeda, T. and Masuda, R. 2008. Genetic identification of mammalian carnivore species in the Kushiro Wetland, eastern Hokkaido, Japan, by analysis of fecal DNA. Zoological Science 25: 714-720.

Shimatani, Y., Takeshita, T., Tatsuzawa, S., Ikeda, T. and Masuda, R. 2010. Sex determination and individual identification of American minks (Neovison vison) on Hokkaido, northern Japan, by fecal DNA analysis. Zoological Science 27: 243-247.

Sobey, D. G. 2007. An analysis of the historical records for the native mammalian fauna of Prince Edward Island. Canadian FieldNaturalist 121: 384-396.

Soulsbury, C. D., Baker, P. J., Iossa, G. and Harris, S. 2010. Red Foxes (Vulpes vulpes). In (Gehrt, S. D., Riley, S. P. D. and Cypher, B. L., eds.) Urban Carnivores. Ecology, Conflict, and Conservation, pp. 63-75. The Johns Hopkins University Press, Baltimore.

Stansbury, C. R., Ausband, D. E., Zager, P., Mack, C. M., Miller, C. R., Pennell, M. W. and Waits, L. P. 2014. A long-term population monitoring approach for a wide-ranging carnivore: noninvasive genetic sampling of gray wolf rendezvous sites in Idaho, USA. Journal of Wildlife Management 78: 1040-1049.

Statham, M. J., Rich, A. C., Lisius, S. K. and Sacks, B. N. 2012. Discovery of a remnant population of Sierra Nevada red fox (Vulpes vulpes necator). Northwest Science 86: 122-132.

Stenglein, J. L., Waits, L. P., Ausband, D. E., Zager, P. and Mack, C. M. 2010. Efficient, noninvasive genetic sampling for monitoring reintroduced wolves. Journal of Wildlife Management 74: 1050 1058.

Sugawara, S. and Komatsu, T. 1959. Hakodate-Yama Shokubutsu-Shi (Flora of Mt. Hakodate). Hakodate City Library, Hakodate, 233 pp. (in Japanese).

Sugimoto, T., Aramilev, V. V., Kerley, L. L., Nagata, J., Miquelle, D. G. and McCullough, D. R. 2013. Noninvasive genetic analyses for estimating population size and genetic diversity of the remaining Far Eastern leopard (Panthera pardus orientalis) population. Conservation Genetics 15: 521-532.

Sugimoto, T., Nagata, J., Aramilev, V. V., Belozor, A., Higashi, S. and McCullough, D. R. 2006. Species and sex identification from faecal samples of sympatric carnivores, Amur leopard and Siberian tiger, in the Russian Far East. Conservation Genetics 7: 799-802.

Sugimoto, T., Nagata, J., Aramilev, V. V. and McCullough, D. R. 2012. Population size estimation of Amur tigers in Russian Far East using noninvasive genetic samples. Journal of Mammalogy 93: 93-101.

Tamura, K., Stecher, G., Peterson, D., Filipski, A. and Kumar, S. 2013. MEGA6: molecular evolutionary genetics analysis version 6.0. Molecular Biology and Evolution 30: 2725-2729.

Tsubouchi, A., Fukui, D., Ueda, M., Tada, K., Toyoshima, S., Takami, K., Tsujimoto, T., Uraguchi, K., Raichev, E., Kaneko, Y., et al. 2012. Comparative molecular phylogeny and evolution of sex chromosome DNA sequences in the family Canidae (Mammalia: Carnivora). Zoological Science 29: 151-161.

Uraguchi, K. 2015. Vulpes vulpes (Linnaeus, 1758). In (Ohdachi, S. D., Ishibashi, Y., Iwasa, M. A., Fukui, D. and Saitoh, T., eds.) The Wild Mammals of Japan, Second edition, pp. 222-223. Shoukadoh, Kyoto.

Valière, N. 2002. GIMLET: a computer program for analysing genetic individual identification data. Molecular Ecology Notes 2: $377-$ 379.

Waits, L. P., Luikart, G. and Taberlet, P. 2001. Estimating the probability of identity among genotypes in natural populations: cautions and guidelines. Molecular Ecology 10: 249-256.

Wandeler, P. and Funk, S. M. 2006. Short microsatellite DNA markers for the red fox (Vulpes vulpes). Molecular Ecology Notes 6: 98-100.

Waples, R. S. and Do, C. 2008. LDNE: a program for estimating effective population size from data on linkage disequilibrium. Molecular Ecology Resource 8: 753-756.

Wilbert, T. R., Woollett, D. A. S., Whitelaw, A., Dart, J., Hoyt, J. R., Galen, S., Ralls, K., Meade, D. E. and Maldonado, J. E. 2015. Non-invasive baseline genetic monitoring of the endangered San Joaquin kit fox on a photovoltaic solar facility. Endangerd Species Research 27: 31-41.

Yoneda, M. and Maekawa, K. 1982. Effects of hunting on age structure and survival rates of red fox in eastern Hokkaido. Journal of Wildlife Management 46: 781-786.

Received 10 August 2017. Accepted 11 April 2018 Published online 13 July 2018. Editor was Jun J. Sato. 

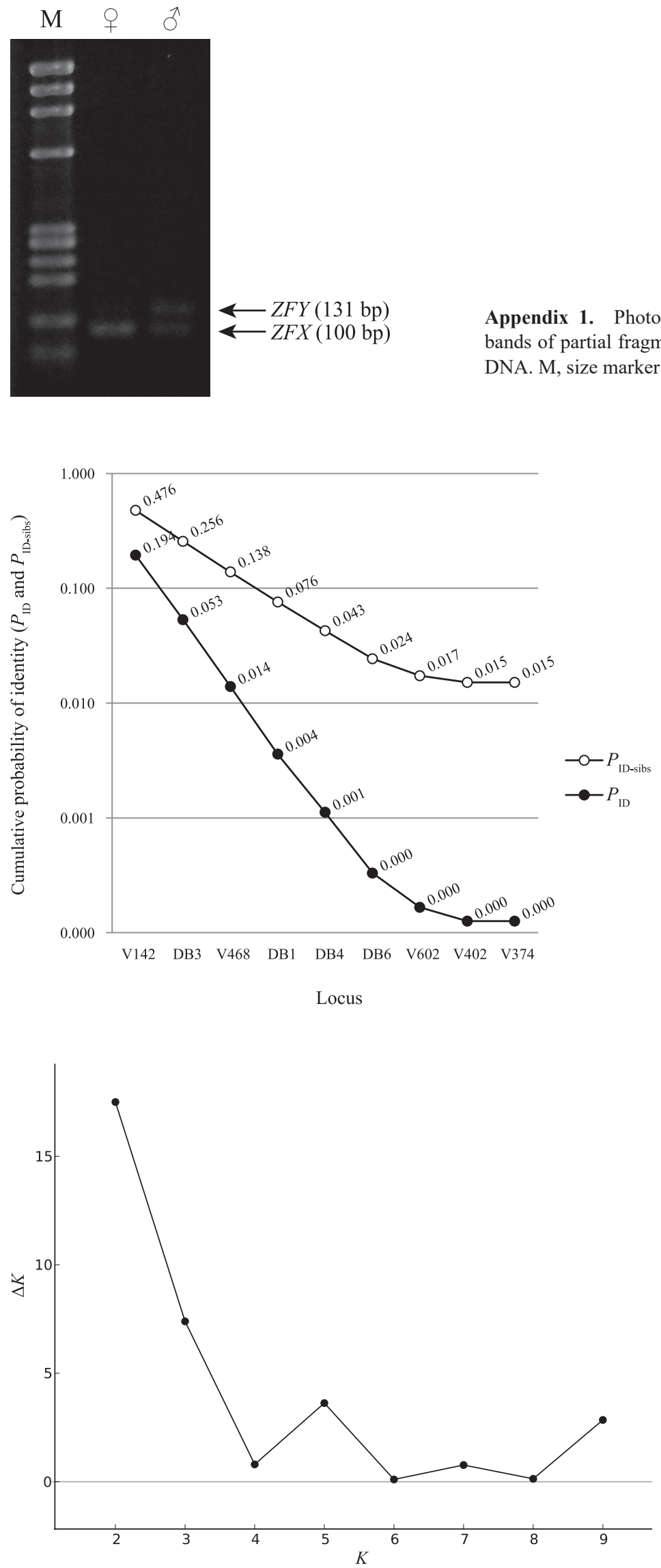

Appendix 1. Photograph of a $3 \%$ agarose gel stained with ethidium bromide, showing bands of partial fragments of the fox $Z F X$ and $Z F Y$ genes amplified by PCR from fecal DNA. M, size marker; $\hat{o}$, male; + , female.
Appendix 2. Semilog plots of the cumulative probabilities of identity $\left(P_{\mathrm{ID}}\right.$ and $\left.P_{\mathrm{ID}-\text { sibs }}\right)$ calculated from fox microsatellite data in this study. The loci were arranged from left to right in order of increasing individual probability values.
Appendix 3. Changes in $\Delta K$ values calculated using STRUCTURE HARVESTER, based on a STRUCTURE analysis of the red fox populations in Hokkaido. 